\title{
POTENTIAL FLOOD IMPACT ON NATURAL AND SOCIOECONOMIC ENVIRONMENT IN RIGA
}

\author{
Jelena MALAHOVA, Faculty of Engineering Economics and Management, Riga Technical University, Kalnciema Street 6, Riga LV- \\ 1048, Latvia; jelena.rtu@ inbox.lv (corresponding author) \\ Daina VASIL,EVSKA, Institute of Management Sciences, Faculty of Management and Social Sciences, Liepaja University, Liela \\ Street 14, Liepaja, LV - 3401, Latvia; daina.vasilevska@gmail.com \\ Karlis KETNERS, Department of Finance, BA School of Business and Finance, Krisjana Valdemara Street 161, Riga, LV-1013, \\ Latvia; k.ketners@gmail.com
}

\begin{abstract}
Flood risk management is the process of data and information gathering, risk analysis and evaluation, appraisal of options, and making, implementing and reviewing decisions to reduce, control, accept or redistribute the flood risks. It is a continuous process of analysis, adjustment and adaptation of policies and actions taken to reduce the flood risk. Preventive measures and timely, reasonable flood risk prevention measures can help reduce the risk of floods and caused damages. In addition, protection against floods is primarily necessary for populated areas, especially when it comes to densely populated areas, since floods may affect a large number of citizens and their property thereby causing enormous material damage not only to the inhabitants of these territories but also to business infrastructure, respectively, it can result in significant material and socioeconomic losses. The aim of the paper is to evaluate the flood risk management theoretical and practical aspects, identify the potential impact of floods on natural and socioeconomic environment, as well as to show the usefulness of flood risk reduction measures. To reach this aim, the following tasks must be fulfilled: to give the definitions of flooding and flood risk and briefly characterise the flooding and flood risk in Latvia; to study and characterize the flood risk management legal and institutional aspects; to carry out an analytical overview of the flood risk assessment on right bank of the Daugava River in Riga; to carry out a cost-benefit analysis of flood risk prevention measures on the right bank of the Daugava in Riga.
\end{abstract}

Keywords: flood risk, flood risk management, flood defence, risk governance

\section{INTRODUCTION}

Flood is a natural phenomenon that can cause social and economic losses, harm to environment and cultural and historical values, endangering human health and safety, therefore, flood modelling and prediction is a great challenge on both state administration and local government level. Floods can be defined as a temporary land cover with water beyond its normal limits (Water Management Law, 2002). In addition to these general conditions, flood can be systematized according to its causes, such as winter rain showers, flooding caused by summer convective storm, spring thaw flooding (or snowmelt originated), sea flooding, tsunami, rising ground water level, city sewer flood, dam rupture or reservoir flood control (Messner et al., 2006). Under Latvian geographical conditions, in winter snow accumulates in river basins and in spring, with coming warm weather, snow starts melting and, as a result, floods occur. In Latvian territory, maximum statistic quantity of flood runoff is greater than rainfall flood peaks. Due to natural regulating operation of river basins, melting snow water flows into a river with a certain delay, firstly accumulating in the mass of snow, therefore the snowmelt peak intensity occurs earlier than the maximum intensity of melting snow water return (LEGMCA, 2017). Compared with the EU Member States, Latvia has low population density, extensive construction development and land use, because of which riverbeds in many sections are still in natural condition. Rivers are featured by a wide floodplain, preserved wetlands and marshes serving as natural flood retention areas (Sugden, 2005). According to the authors, the abovementioned does not diminish the topicality of flood issues in Latvia, quite on the contrary, flood problems in Latvia are essential every year, especially in spring floods, because principal cause of flooding in Latvia is ice jams, andfloods in Latvia are observed relatively often due to repetition trend.

The present study aims to reflect the flood risk management theoretical and practical aspects, to identify the potential impact of floods on the natural and socio-economic environment and evaluate the effect of flood mitigation measures. The study includes an analytical review of the flood risk assessment on the right bank of Daugava River in Riga as well as a cost-benefit analysis of flood mitigation measures on the right bank of Daugava River in Riga. Methodology of the study is generally based on Ministry of Environment and Regional Development (VARAM) methodology "Criteria and Methodology for the Assessment of Flood Risk Reduction Measures" (Criteria and distribution, and reproduction in any medium, provided the original author and source are credited. 
Methodology for the Assessment of Flood, 2015), analysis of costs and benefits is mainly based on the European Commission's guidelines “Guide to Cost-Benefit Analysis of Investment Projects (Guide to Cost-Benefit Analysis, 2014); methodology of cost-benefit analysis developed by the Republic of Latvia Ministry of Environment and Regional Development (hereinafter referred to as IIA Methodology (Methodology, 2014), and Guidelines for Socio-economic Flood Damage Evaluation (Messner et al., 2006).

\section{RESEARCH RESULTS AND DISCUSSION}

Climate in Riga is influenced by sea, it is moderately warm and humid. Approximately $40 \%$ of days per year are cloudy, precipitation - 700-720 mm a year (LEGMCA, 2017). Construction and other activities in the flood zones are restricted in accordance with the Law on Protection Zones (Law on Protection Zones, 2014).

Flood protection system existing in Riga (polders, sewage pumping stations, dykes, water level regulators etc.) fairly well protects the city from wind surges, which in the Daugava mouth do not exceed two meters. BBBut one has to note that Riga has no protection against floods where water level is higher than 2 meters. Forecasts suggest that future climate changes will significantly increase the flood areas. It is explained by overall water level rise. Taking into account the expectations of modern climate conditions with the return period of 100 years $(1 \%)$, the water level in Daugavgriva rises up to 2.19 meters from the datum in the Baltic Sea System. It is expected that in the second half of the century at the same flood probability the water level will already reach 2.60 mark. The largest water body Daugava's length within the cityterritory is $\sim 31 \mathrm{~km}$, widthat bridges $700 \mathrm{~m}$, depth 8-15 m (Maritime Administration of Latvia, 2014).

Appropriate preventive measures and timely and reasonable flood mitigation measures can help reduce the risk of floods. Flood risk is formed by flood probability and possible consequences. In addition, protection against floods is primarily required for populated areas, especially when it comes to densely populated areas, because in such cases floods may affect a large number of citizens and their property, thereby causing enormous material damage not only to inhabitants of these territories but also to the business infrastructure, respectively contributing to considerable material and socio-economic losses. When planning the flood risk mitigation or minimization activities, it is primarily necessary to identify the flooding probability in a given area as well as to assess the potential anti-flood protection measures, identifying and analyzing various alternatives that could provide the greatest socio-economic benefits and efficiency. The studied area - Kengarags embankment from Kaniera Street to Kvadrata Street - is located in southeast part of the city. Kengarags region is a locality in southeast part of Riga, bordering Moscow suburb, Shkirotava and Rumbula neighbourhoods and along the South Bridge also Katlakalna neighborhood. Flood threats caused by spring tides are topical exactly for the territory examined - Kengarags embankment from Kaniera Street to Kvadrata Street, as coastline is not straight and there is a possibility for formation of ice jams which later increase flood risk.

\section{METHODS OF ASSESSMENT OF FLOOD RISK TERRITORY}

Global trends present evidence that because of climate changes and the resulting general rise in water level the territories flooded will expand. However, taking into account the limited country resources, in any case one should evaluate in which territories flood protection measures should be implemented in priority and which territories are not so important and the threat level is not so threatening. Consequently, each case should be studied individually. The assessment of flood risk territories (studied territories) have been performed by authors using VARAM methodology "Criteria and Methods of Assessment of Flood Risk Reduction Measures" (further in the text also - Methods) (Criteria and Methodology for the Assessment of Flood, 2015).

Protection against floods is primarily necessary for populated areas, since floods may affect a large number of citizens and their property. Thus, the first criterion "The Number of Inhabitants" highlights those flood risk territories which will affect a large number of citizens, the criteria is evaluated by granting score points from 0 to 100 based on number of citizens in flood risk territories (e.g. the number of people living in the areas affected by floods more than 10 000 citizens -100 points, the number of people living in the areas affected by floods more than 5000 citizens -75 points etc.). Assessment of studied territory: in Kengarags region there live 32714 citizens, consequently, assuming that flood to a greater or lesser extent would affect all the people in the region, criterion assessment is 100 points.

Under the impact of flood, being underwater for a long time or in the grip of current flow, the objects of existing infrastructure can be damaged. Roads are a significant object of infrastructure. Roads are the possibility for citizens to escape from flood affected territories as well as for rescue services to access the places affected by natural disasters and provide first necessary aid. The larger part of road network is affected during floods the more burdensome are actions in flood territory. Motor roads, highways and first class roads are considered to be major roads.

The next criterion "Major Roads" highlights those flood risk territories as a result of which major roads will be affected (Criteria and Methodology for the Assessment of Flood, 2015). Based on scoring approach under criteria „Major roads are in flood affected territories" if flood affected territories will be affected more than $10 \mathrm{~km}$ of major roads - 100 points are applicable, if more than $0.5 \mathrm{~km}-50$ points. According to the assessment of studied territory: road and street tracks in Kengarags locality occupy 62, 8 ha. In direct impact zone of studied territory a potential risk zone is identified - Maskavas Street is A6 category or highest category motor road. Assuming that as a result of flood the road from Kaniera Street till Kvadrata Street, i.e. $2 \mathrm{~km}$, will be affected the criteria assessment is 50 points. Based on assessment of studied territory criterion assessment for "HPP are in flood affected territories", Polders are in flood affected territories" is neutral (Criteria and Methodology for the Assessment of Flood, 2015). 
Assessment of studied territory also shows that comparatively insignificant environmental pollution can be caused by discharge of sewage in the yards of territories in case of flood risk. However, the amount of melting and rain water is large, that is why the pollution would be diluted reducing damage to environment. Riga central waste water purification is ensured by Biological purification station "Daugavgriva". In the territory studied there are no waste water purification stations. In the studied territory 2 potentially polluted places are identified - close to Kaniera Street in Kengaraga Street 6 there is "Revija Pluss" ltd. former fishing net production and colour shop, in its turn, in studied territory section in Maskavas Street 349b there is "Latvia Statoil" ltd., former Latvijas Nafta petrol station where lasting leakage of oil products into soil has been found. Thus, criterion assessment is 25 points.

The next criterion "Specially Protected Areas" highlights the flood risk territories as a result of which specially protected natural areas will be affected. Specially protected territories, such as nature parks, nature reserves ans so on, may be exposed to greater flooding, especially under impact of large flood being underwater for a long time. But one should take into account that this criterion applies only to small and medium probability of floods (with recurrence frequency once in 100 or 200 years), as great probability floods in such territories are preferable. Also within the border of Riga administrative territory possible flooding does not threaten specially protected natural territories and does not trouble the implementation of protection functions (Riga City Council Project, 2011). In the territory studied specially protected natural areas are not found according to the data of Nature Data Management Systems (National Nature Data Management System). Consequently, the criterion assessment is 0 points. Under the impact of flood, being underwater for a long time or in the grip of current flow, agricultural production can be destroyed, as well as land can be degraded by washing away fertile land surface. As a result, production of agricultural products is impossible or bothered in future. However, there are no agricultural lands in studied territory, so the criterion assessment is 0 points. Under the influence of flood, pollution spreading, including from polluted or potentially polluted places, it can reach existing infrastructure objects that help to ensure drinking water supply.

The next criterion "Water Intake Places" highlights those flood risk territories as a result of which municipal water intake places with average amount of water supply is larger than $100 \mathrm{~m} 3 / \mathrm{d}$ will be affected (Criteria and Methodology for the Assessment of Flood, 2015). According to the assessment of studied territory: biggest part of drinking water users on the left bank of Daugava in Riga receives water from the Daugava river basin in Riga HPP water reservoir zone. The water is taken from the deepest layers of the river and is delivered with the assistance of pumps through pipelines to water station "Daugava" where they are prepared according to the requirements of drinking water quality, using chemical agents is purified, disinfected, let settle and multiply filtered.

As it is shown in the table 1 , of total possible maximum number of points $=750$ in the Methodology assessment, the studied territory is evaluated with 175 points, which is comparatively assessed as a low figure and the flood risk territory would not be considered as priority. Only four criteria are assessed and discussed, as the other four are not present at the studied area. However, it should be noted that the maximum number of points is a criterion in relation to the number of inhabitants and as already mentioned above just the inhabitants are an element that in case of flood risk occurrence is the most unprotected. Therefore it is important to reduce the flood risk also in this territory with a very high population density and built-up of mainly residential buildings, which in case of flood risk occurrence would essentially increase the potential damages.

Table 1. Summary of the studied territory assessment

\begin{tabular}{|l|c|}
\hline \multicolumn{1}{|c|}{ Criterion } & Points \\
\hline Number of citizens in flood risk territories & 100 \\
\hline Major roads are in flood affected territories & 50 \\
\hline HPP are in flood affected areas & 0 \\
\hline Polders are in flood affected areas & 0 \\
\hline Flood affected territories with STP, polluted or potentially polluted areas & 25 \\
\hline Specially protected natural areas are in flood affected territories & 0 \\
\hline Agricultural lands are in flood affected areas & 0 \\
\hline $\begin{array}{l}\text { In flood affected territories there are water intake places with average amount of water taken more than } 100 \\
\text { m3/d }\end{array}$ & 0 \\
\hline
\end{tabular}

In the elaboration of the plan or reduction of flood risk it is essential not only to examine different possible flood risk reduction scenarios, but also evaluate the factors definite chosen scenarios would affect in the most essential positive way, i.e. they would be maximally effective both in terms of technical performance and economics.

Costs of investments in flood risk prevention plan would mainly consist of construction costs (see table 2). For determination of construction costs the authors used the costs estimated by Riga City Council in 2016, indexing them by 1.1 (the approximate increase in prices in construction sector).

Table 2. Investment costs, VAT incl., EUR

\begin{tabular}{|l|c|}
\hline & VAT incl., EUR \\
\hline Construction costs & $2,554,582$ \\
\hline Building supervision costs & 30,910 \\
\hline Designer's supervision costs & 61,821 \\
\hline Total & $2,647,314$ \\
\hline
\end{tabular}


The costs in Table 3 and Table 4 are determined based on estimates of damages indicated in the Project "Integrated Strategy for Riga City to Adapt to the Hydrological Processes Intensified by Climate Change Phenomena" (Riga City Council Project, 2011) indexing the estimated prices by 1.1 .

Table 3. Built-up territories used in damage estimates and therewith associated flood-caused damages (EUR/m²)

\begin{tabular}{|l|l|c|}
\hline No. & \multicolumn{1}{|c|}{ Type of territory } & EUR/m \\
\hline $\mathbf{1}$ & Plantation and natural territory & 0.06 \\
\hline $\mathbf{2}$ & Paved roads & 1.10 \\
\hline $\mathbf{3}$ & Unpaved roads & 0.39 \\
\hline $\mathbf{4}$ & Built-up territory of centres & 0.39 \\
\hline $\mathbf{5}$ & Residential built-up territory & 0.31 \\
\hline $\mathbf{6}$ & Mixed territory & 0.31 \\
\hline $\mathbf{7}$ & Production and business built-up territory & 0.13 \\
\hline $\mathbf{8}$ & Technical built-up territory & 0.09 \\
\hline
\end{tabular}

However, taking into consideration that the built-up environment in possible flood area is rather worn and partly is in final stage of service cycle as well as that a part of buildings consists of auxiliary structures (garages etc.), then values of damages used estimates were applied average within the limits of $70 \%$ from those indicated in Table 4.

Table 4. Real estate used in damage estimates and therewith associated flood-caused damages $\left(\mathrm{EUR} / \mathrm{m}^{2}\right)$

\begin{tabular}{|c|l|c|}
\hline No. & \multicolumn{1}{|c|}{ Type of built-up environment } & EUR/m \\
\hline $\mathbf{1}$ & Low-rise residential build development & 50 \\
\hline $\mathbf{2}$ & High-rise residential build development & 38 \\
\hline $\mathbf{3}$ & Social build development & 38 \\
\hline $\mathbf{4}$ & Production premises & 19 \\
\hline $\mathbf{5}$ & Warehouses and logistics centres & 16 \\
\hline
\end{tabular}

The planned investments do not ensure direct revenues, therefore the plan implementation needs an additional financing. According to estimates by the authors, it is evident that the investment performance is negative during the chosen period of plan analysis (Financial net present value of investments (FNPV) is -1,712,750 EUR). Negative investment performance is a characteristic feature of public infrastructure development projects or plans, especially of projects or plans that do not generate the activity incomes.

According to the Methodology, the socioeconomic analysis should be carried out for projects or plans with FNPV $<0$. Benefits and costs should be assessed for them in order to estimate benefits and costs of society in case the plan is realized. Taking into consideration the objective restrictions, within the framework of the plan socioeconomic analysis both direct and main indirect material benefits are expressed quantitatively, which is associated with estimate of the Plan territory's economic value since the direct material benefits only are not enough to objectively reflect the true socioeconomic value of the Plan.

All other possible socioeconomic benefits through the lack of information within the framework of the present Plan are referred to nonmonetary benefits. Taking into consideration that the quantification of abovementioned socioeconomic losses is not possible through the lack of information, within the framework of the present Plan they are referred to the nonmonetary losses.

The following benefits have been identified and taken into account in the analysis (see table 5).

Table 5. Socioeconomic benefits

\begin{tabular}{|l|l|}
\hline \multicolumn{1}{|c|}{ Indicator } & \multicolumn{1}{c|}{ Basis of estimate } \\
\hline $\begin{array}{l}\text { Growth in value of } \\
\text { buildings }\end{array}$ & $\begin{array}{l}\text { Since the estimate of market value of total residential area is not available, the cadastral value of } \\
\text { residential area of directly adjacent buildings was used in accordance with data of www.kadastrs.lv. } \\
\text { It is assumed that the river front cleanup and flood risk reduction rather directly influenced the life } \\
\text { quality of inhabitants of adjacent buildings, and it is assumed that the building values could increase } \\
\text { by 10\% during the next 3 years after completion of the plan. }\end{array}$ \\
\hline $\begin{array}{l}\text { Growth in value of } \\
\text { land }\end{array}$ & $\begin{array}{l}\text { Reconstruction of the riverfront area, reduction of the flood risk and cleanup of the territory will } \\
\text { promote the living environment quality, directly affecting the welfare of inhabitants of adjacent } \\
\text { buildings and generally all residents of Kengarags district. It is assumed that approximate average } \\
\text { value of Kengarags land is 36 EUR/m } 2 \text { and prevention of flood risk and improvement of living } \\
\text { environment quality will ensure 1\% growth in the land value. }\end{array}$ \\
\hline $\begin{array}{l}\text { Devastation } \\
\text { prevention }\end{array}$ & $\begin{array}{l}\text { Territory protection against potential flood reduced the possibility of flooding. Estimating the } \\
\text { potential damages that could be caused by flood and multiplying them by the yearly flooding } \\
\text { probability, we obtain the yearly benefits from the flood risk reduction. The flooding damages are } \\
\text { estimated taking into account the potentially floodable buildings area and potentially floodable } \\
\text { territory area, and multiplying by the estimated damages. The risk of flooding is once in 200 years at } \\
\text { present time but without reconstruction of anti-flood infrastructure the flood probability will increase } \\
\text { and after 10 years since completion of the plan will be one in 100 years. }\end{array}$ \\
\hline Saved costs & $\begin{array}{l}\text { The Plan will allow to save regular costs that would appear each year establishing temporary } \\
\text { reinforcements of the anti-flood infrastructure. These costs are estimated in the amount of EUR 1,718 } \\
\text { per year starting with the plan commencement year. }\end{array}$ \\
\hline
\end{tabular}


Taking into consideration the indirect benefits, the socioeconomic analysis indicators have been estimated (see Table 6).

Table 6. Socioeconomic analysis indicators

\begin{tabular}{|l|l|l|l|}
\hline No. & \multicolumn{1}{|c|}{$\begin{array}{c}\text { Main parameters and } \\
\text { indicators }\end{array}$} & Value & \multicolumn{1}{c|}{ Explanation } \\
\hline 1 & $\begin{array}{l}\text { Economic net present value } \\
(\text { ENPV) }\end{array}$ & 582,201 & Plan should have positive present value. \\
\hline 2 & Economic rate of return (ERR) & $11,17 \%$ & $\begin{array}{l}\text { ERR is higher than the accepted social discount rate (5\%), therefore the } \\
\text { plan is economically beneficial for society. }\end{array}$ \\
\hline 3 & Benefit-cost ratio (B/C) & 1,29 & $\begin{array}{l}\text { If indicator is higher than 1, them incomes and benefits (financial and } \\
\text { socioeconomic) created by the plan exceed the costs and damages } \\
\text { (financial and socioeconomic). }\end{array}$ \\
\hline
\end{tabular}

\section{CONCLUSIONS}

Main attention of flood risk management measures is paid to prevention. Measures to be taken within the framework of the plan, acting for the benefit of nature and not against it, protecting people, property and environment and helping to provide an environment-friendly sustainable water management as well as to reach the EU biological diversity objective and implement the EU strategy regarding the adaptation to climate changes.

There are various problems existing in the field flood threat prevention and several engineering solutions for reinforcement of the Daugava bank, also in Kengarags district are developed; however, these developed engineering solutions are periodically realized only partly since the local government has no enough resources to carry out reconstruction works on the entire riverfront.

Of total possible maximum number of points $=750$ in the Methodology assessment, the studied territory is evaluated with 175 points, which is comparatively assessed as a low figure and the flood risk territory would not be considered as priority. However, it should be noted that the maximum number of points, 100 , is a criterion in relation to the number of inhabitants and, as already mentioned above, just the inhabitants are an element that in case of flood risk occurrence is the most unprotected. Therefore it is important to reduce the flood risk also in this territory with a very high population density and built-up of mainly residential buildings, which in case of flood risk occurrence would essentially increase the potential damages, especially those from harm done to the property.

It is essential to assess not only the significance of threat to national importance facilities but also those socioeconomic losses or benefits that would be expected from the flood risk reduction in such territory which is of conditionally less national importance.

Even at most pessimistic forecast where the values of all socioeconomic indicators anticipated in the plan would decrease by $15 \%$ or the investment costs would grow by $15 \%$, which is very possible under present unstable market conditions, the plan outcomes remain positive. Therefore it can be concluded that changes in socioeconomic situation may leave an insignificant impact on the plan outcomes. Economic assessment of the plan in case of pessimistic scenario is neutral, therewith it can be concluded that in case of worst outcome of the plan the society's benefits will fully compensate the investments.

\section{REFERENCES}

1. Baltic Sea Pilot. Latvian Coast. Maritime Administration of Latvia, 2014. Available at: https://www.lja.lv/sites/default/files/page_attachments/locija_en_sep.pd f

2. Criteria and Methodology for the Assessment of Flood Risk Reduction Measures". 2015. Available at: http://www.varam.gov.lv/in_site/tools/download.php?file=files/text/Publikacijas/petijumi/vide//Pludu_riski_Zinojums_4_versija _gala.pdf Accessed on 09/10/2017) [In Latvian].

3. Dottori, F., Martina, M.L.V., Figueiredo, R. 2016. A methodology for flood susceptibility and vulnerability analysis in complex flood scenarios. Journal of Flood Risk Management. https://doi.org/10.1111/jfr3.12234

4. Flood risk areas. Latvian Environment, Geology and Meteorology Centre (LEGMC). Available at: https://www.meteo.lv/pakalpojumi/hidrometeorologiska-informacija/hidrologiska-informacija/?\&nid=540\&cid=941(accessed on 10/05/2017)

5. Flood risk assessment and flood risk management. 2009. Available at: http://www.floodsite.net/html/partner_area/search_results3b.asp?docID=798 (accessed on 10/12/2017)

6. Grist, J.P., Josey, S.A., Zika, J.D., Evans, D.G., Skliris, N. 2016. Assessing recent air-sea freshwater flux changes using a surface temperature-salinity space framework. Journal of Geophysical Research, Vol. 121(12), pp. $8787-8806$. https://doi.org/10.1002/2016JC012091

7. Guide to Cost-Benefit Analysis of Investment Project. Economic appraisal tool for Cohesion Policy 2014-2020. http://ec.europa.eu/regional_policy/sources/docgener/studies/pdf/cba_guide.pdf (Acessed on 09/09/2017)

8. Law on Protection Zones. Available at: https://likumi.lv/ta/id/42348-aizsargjoslu-likums 25.02.1997. [In Latvian].

9. Messner, F., Meyer, V. 2006. Guidelines for Socio-economic Flood Damage Evaluation. Available at: http://www.floodsite.net/html/partner_area/project_docs/T9_06_01_Flood_damage_guidelines_D9_1_v1_0_p01.pdf

10. Methodology "Criteria and Methodology for the Assessment of Flood Risk Reduction Measures". 2014. Available at: http://www.varam.gov.lv/lat/fondi/kohez/2014_2020/?doc=21317 [In Latvian] 
11. National Nature Data Management System. Available at: https://www.daba.gov.lv/public/eng/protected areas/

12. Petersen, G. 2009. Managing Extreme Flood Events. German IHP/HWRP National Committee, 106 p.

13. Riga City Council Project: „Integrated Strategy for Riga City to Adapt to the Hydrological Processes Intensified by Climate Change Phenomena". Riga:2011, 41 p. Available at: http://ec.europa.eu/environment/life/project/ [In Latvian]

14. Sugden, R. Integrating Cost-Benefit Analysis and Multi-Criteria Analysis of Flood and Coastal Erosion Risk Management Projects (DEFRA R\&D Project Record FD2018/PR2. London: Department for Environment Food and Rural Affairs, 2005, 17 p. Available at: http://evidence.environment-agency.gov.uk/FCERM/Libraries/FCERM_Project_Documents/FD2018_5184_PR_pdf.sflb.ashx (Accessed on 10/25/2017)

15. Water Management Law. (12.09.2002.) Available at: https://likumi.lv/ta/id/66885-udens-apsaimniekosanas-likums [In Latvian] 